\title{
DISSOLVED ORGANIC CARBON AND BIOAVAILABILITY OF N AND P AS INDICATORS OF SOIL QUALITY
}

\author{
Maria Lucia Azevedo Silveira \\ University of Florida, Soil and Water Science Department, PO Box 110510, Gainesville, FL, USA. 32607 - e-mail \\ <mlsilveira@ifas.ufl.edu4>
}

\begin{abstract}
Soil quality has become an important issue in soil science. Considerable attempts have been made to define soil quality, but a general concept has not yet been accepted by the scientific community. The selection of quantitative indices for soil quality is extremely difficult, and a considerable number of chemical, physical, and biochemical properties have been suggested as potential indicators of soil quality. Because soil organic matter (SOM) can be associated with different soil chemical, physical and biological processes, it has been widely considered as one of the best soil quality indicator. Land use can significantly influence dynamics of organic carbon and N, P, and S cycle. However, changes in total soil organic carbon (SOC) contents in response to land use may be difficult to detect because of the natural soil variability. In the short to medium term, biological properties and readily decomposable fractions of SOC, such as dissolved organic carbon (DOC), are much more sensitive to soil management than is SOM as a whole, and can be used as a key indicator of soil natural functions. Despite the fact that labile $\mathrm{C}$ accounts for a small portion of the total organic matter in the soils, DOC is the most mobile and important C-source for microorganisms, and can easily reflect the effects of land use on soil quality. Although several methods are used to characterize DOC, the factors influencing mineralization and bioavailability of elements associated with organic matter (N, P, and S) remains unclear. Future research should focus on the processes that govern DOC and nutrient dynamics and how they affect soil quality.
\end{abstract}

Key words: ecosystem management, sustainability, indicators of soil quality.

\section{CARBONO ORGÂNICO DISSOLVIDO E BIODISPONIBILIDADE DE N E P COMO INDICADORES DE QUALIDADE DO SOLO}

\begin{abstract}
RESUMO: Nas últimas décadas, qualidade do solo tem se tornado um tópico importante na ciência do solo. Embora esforços consideráveis tenham sido dedicados com o intuito de definir "qualidade do solo", ainda não há um conceito amplamente aceito pela comunidade cientifica. A seleção de índices qualitativos para definir qualidade do solo é uma tarefa extremamente difícil, e diversas propriedades químicas, físicas e biológicas tem sido sugeridas como potenciais indicadores. A matéria orgânica do solo está associada com processos químicos, físicos e biológicos no solo, e, portanto, é considerada um dos melhores indicadores de qualidade do solo. O manejo do solo pode influenciar significativamente a dinâmica do carbono orgânico e o ciclo de N, P, e S. Entretanto, mudanças na concentração total da matéria organica em resposta ao manejo pode ser dificil de ser detectada devido à variabilidade natural do solo. Quando comparada com a matéria orgânica total do solo, a fração mais prontamente disponível, como o carbono orgânico dissolvido (COD), é mais sensível às mudanças no manejo do solo a curto e médio prazo e, portanto, pode ser utilizada como indicador fundamental de qualidade do solo ou das alterações das condições naturais. Embora a fração dissolvida represente apenas uma pequena porção da matéria orgânica total do solo, o COD é móvel no solo e constitui uma importante fonte de $\mathrm{C}$ para os microorganismos, podendo facilmente refletir os efeitos de diferentes sistemas de manejo. Inúmeros métodos são utilizados para caracterizar o COD, mas os processos que influenciam sua mineralização e a disponibilidade dos elementos associado com a matéria orgânica (N, P, e S) ainda não são completamente entendidos. Pesquisas futuras devem buscar entender os processos que governam a dinâmica de nutrientes e do COD e como os mesmos afetam a qualidade do solo.

Palavras-chave: manejo do ecossistema, sustentabilidade, indicadores de qualidade do solo
\end{abstract}

\section{INTRODUCTION}

Concern over accelerated soil degradation has directed attention towards assessment of soil sustainability.
Definitions of sustainability and soil quality can be based on ecological, economical, social and political issues. Soil quality (SQ), when defined as "the capacity of a specific kind of soil to function, within natural or managed eco- 
system boundaries, to sustain plant and animal productivity, maintain or enhance water and air quality, and support human health and habitation", covers a range of outputs including ecosystem productivity, water quality and energy balances (Karlen et al., 1997; Carter, 2002). In spite of the large number of scientific papers dealing with soil quality, only a few attempted to estimate and quantify the level of soil quality (Gil-Sotre et al., 2005). No measure can index all of these landscape outputs; therefore, the specific definition of SQ must be subjective and dependent on the user's goals and/or specific ecosystem function. For instance, the goal may be crop yield, biodiversity or environmental protection. Consequently, the selection of indicators may be different for each goal.

Soil quality indicators are not well defined; nor are there accepted or approved parameters known to characterize or to define soil quality (Bouma, 2002). Many soil ecosystems functions are difficult to infer directly and, consequently, SQ must often be inferred from other easily measurable soil properties (Weil \& Magdoff, 2004). Physical (e.g., aggregation, bulk density), chemical (e.g., $\mathrm{pH}$, salinity, exchangeable cations) and biological indicators (e.g., microbial biomass, enzyme activity, basal respiration) have all been suggested as SQ indicators. A SQ indicator should ideally be (i) easily measurable, (ii) seasonally stable, but (iii) sensitive to changes in ecosystem functions that determine the user's goal. However, one of the main premises of this concept is that better indicators of SQ are not individual soil characteristics or process measurements that meet the above criteria, but output from mechanistic models that incorporate and synthesize soil-based processes that define the user's goal.

If the goal is to index a soil's quality for plant production, then soil organic matter, infiltration, soil aggregation, $\mathrm{pH}$, microbial biomass, forms of $\mathrm{N}$, bulk density, topsoil depth, conductivity or salinity, and extractable nutrients, represent the range of indicators that have been used. Soil organic carbon (SOC) is an extremely important soil attribute (Haynes, 2005) and has been considered one of the most important indicators of soil quality because plays important role in the maintenance of soil structure, water-holding capacity, microorganisms, and nutrient cycling (Goulding et al., 2000).

SOC is the net result of carbon input and mineralization in the soil. Input tends to increase with increasing yield, while mineralization is more a function of the environment (temperature and moisture). SOC is closely linked to soil's water retention capacity, nutrient availability, structural stability, and soil compaction. Additionally, changes in soil physical characteristics resulting from erosion of surface layers and losses of soil particles and nutrients also affect SOC contents and composition. In short, SOC and its components are related to a set of soil chemical, physical and biological attributes, as well as temporal and spatial variations.
Nevertheless, changes in total SOC content in response to land use may be difficult to detect because of the natural soil variability (Haynes \& Beare, 1996). Recently, studies showed that dissolved organic carbon (DOC) contents and soil attributes are sensitive to changes in total SOC. In the short to medium term, biological properties and the readily decomposable fraction of SOC, such as DOC, are much more sensitive to soil management than is SOM as a whole. DOC concentration and composition are related to land management and the quality of crop residue. Particulate organic matter (POM), for instance, was found to be the fraction preferentially lost when soils were converted from pastures to cropping. Chan et al. (2002) found that $\mathrm{POM}$ is a more sensitive indicator of management-induced changes than total SOC, and it was related to water stability of aggregates and mineralization of nitrogen.

Components of SOC associated with multivalent cations (e.g. $\mathrm{Al}, \mathrm{Fe}$, and $\mathrm{Ca}$ ) and clay particles are more resistant to decomposition, with turnover times measured in hundreds to thousands of years. DOC reflects the equilibrium between dissolved and solid phases, and is closely related to microbial activity, thereby being a sensitive indicator of total SOM and changes in soil management and, by extension, soil quality. Additionally, transport and bioavailability of metal and organic pollutants in contaminated areas are also affected by DOC dynamics (Zsolnay, 1996).

\section{Dissolved organic carbon}

Issuing a general, chemical definition of DOC is an impossible task; it is operationally defined as all organic substances smaller than $0.45 \mu \mathrm{m}$. This material is distributed among different pore sizes and structures (Kalbitz et al., 2000). DOC can be classified as DOM I, DOM II and DOM III (Zsolnay, 1996). DOM I corresponds to DOC in microaggregates and it is not bioavailable, since it is physically protected from microorganisms (by the microaggrates). However, if exposed by disturbance, it is a viable form of energy for microorganisms. Conversely, DOM III, found in macroaggregates, is metabolized by microheterotrophs. Attributes of DOM II, the mesoaggregate fraction, lie somewhere between DOM I and DOM II. The mesoaggregate and microaggregate DOM might not be assessable in laboratory studies without disturbing the sample (Chantigny, 2003). Water-Extractable-Organic Carbon (WEOC) is the fraction of the SOC released by extracting soil samples with aqueous solution under agitated conditions (DOM III, and some of DOM I and II).

Particulate organic carbon (POC) is defined as organic carbon retained on a $0.45 \mu \mathrm{m}$ filter, inferring that the colloidal material is usually considered to be part of 
the dissolved phase. Qualls et al. (1991) supported this contention by showing that POM does not exceed 3\% of the DOC.

Methods used to extract DOC affect its attributes as well as the amount extracted. Generally, DOC can be extracted using batch or column experiments. In lieu of simplicity, many researchers have extracted DOC using distilled water. However, experimental conditions such as soil:solution ratio, temperature, contact time, agitation method and preparation and storage of soil samples should be considered because they influence the composition of the extracted solution. Salt extracts have been also used to extract DOC from field-moist soils. For instance, $0.5 \mathrm{~mol} \mathrm{~L}^{-1} \mathrm{~K}_{2} \mathrm{SO}_{4}$ have been used as indicator of soluble C (Haynes, 1999). However, when using salt solutions to extract DOC, one should be aware that concentrations may differ from those measured by water extraction (Haynes, 2005).

Dissolved organic nitrogen (DON), dissolved organic phosphorus (DOP), water-extractable organic nitrogen (WEON), and water-extractable organic phosphorus (WEOP) can be analyzed in the same DOC extract. As much as $90 \%$ of N, $50 \%$ of $\mathrm{P}$ and $90 \%$ of S occur in organic forms. Qualls et al. (1991) found that organic $\mathrm{N}$ and $\mathrm{P}$ were the dominant forms of these nutrients in forest soils due to both the addition of organic forms and a removal or transformation of inorganic forms, as throughfall percolated through the soil.

Despite the fact that DOC and WEOC account for a small portion of total SOC, these fractions markedly influence soils chemical, biological, and physical properties, as primary sources of mineralizable $\mathrm{C}, \mathrm{N}, \mathrm{P}$, and $\mathrm{S}$ (Haynes, 2000). In aquatic ecosystems, DOC is the largest pool of organic material. DOC is also considered a mobile, important $\mathrm{C}$-source for microorganisms. Measuring the production of $\mathrm{CO}_{2}$ can determine if DOC works as substrate for microorganisms (Zsolnay, 1996). However, DOC degradability is variable, presumably as a result of variations in SOC quality and structure (sugars, proteins, phenols, tann ins contents). These attributes have been related to the density of the SOC. Kalbitz et al. (2000) reported that about $10-40 \%$ of DOC might be easily decomposable by microorganism in a period ranging from days to a few months. However, these authors suggested also that it is impossible to precisely quantify microbial degradation of DOC in mineral soils because of adsorption reactions protect DOC against degradation.

DOC is a heterogeneous phase, represented by different classes of acids, bases and neutral compounds with varying degradability rates; humic substances are generally the largest fraction (Qualls \& Richardson, 2003). Aromatic structures are more recalcitrant than aliphatic structures and, consequently, are more stable. Hydrophobic compounds are less accessible to microbial degradation than hydrophilic molecules. Presumably, this may be due to the higher affinity of hydrophobic components of DOC to be absorbed by clay minerals, which protect them against degradation (Piccolo 1996; Jardine et al. 1989). Also, hydrophobic molecules in soil solution exhibiting long chain, aliphatic or benzene-based compounds are protected from microbial decomposition, and this concept of hydrophobicity may explain the rate of organic matter turnover in soils (Piccolo, 1996).

Characterization of DOC is difficult because of the high variability of compounds, however the fractionation based on its molecular size has been widely used (Qualls \& Haines, 1991). According the procedure developed by these authors, DOC can be separated into the following fractions, defined by their behavior on nonionic and ion-exchange resins: (i) hydrophobic neutrals, (ii) weak (phenolic) hydrophobic acids, (iii) strong (carboxylic) hydrophobic acids, (iv) hydrophilic acids, (v) hydrophilic neutrals, and (vi) bases. In this context, hydrophobic acid fraction includes the humic substances along with the amino acids and phosphates esters; weak hydrophilic acids (phenols) contain tannins and flavonoids without carboxylic acid groups; and hydrophilic acids may consist of humic-like substances with lower molecular size and higher $\mathrm{COOH}: \mathrm{C}$ ratios, oxidized carbohydrates with carboxylic acid groups, low molecular size carboxylic acids, and sugar phosphates. Hydrophobic neutrals include lipids and some pigments; hydrophilic neutrals may include simple and complex carbohydrates, and bases contain free amino acids and free proteins, which and it might be the more bioavailable substances of the DOC (Qualls et al. 1991).

Hydrophobic and hydrophilic acids are the dominant fractions of DOC (Qualls \& Haines, 1991; Smolander \& Kitune, 2002). In general, the hydrophobic acids contents are reduced with depth, what suggests that a selective net removal of these compounds occurs when DOM percolates through soils horizons. Once again, this may occur because the high affinity of hydrophobic compounds to be absorbed by soils.

The degradability of DOC is closely related to the dynamics of $\mathrm{N}, \mathrm{P}$, and $\mathrm{S}$ in soils and may be affected by external factors such as rainfall, temperature, vegetative cover, and soil properties ( $\mathrm{pH}$, nutrients, salts, $\mathrm{O}_{2}$ ). Some soil components, especially Al, Fe oxides, and clay minerals determine the sorption/desorption between the dissolved and the solid phase of the organic matter in soils. Metal hydrous oxide surfaces can strongly bind DOC through either electrostatic bonding (anion exchange), specific adsorption (i.e. ligand exchange), or physical (Van der Waals) forces (Stevenson, 1994). Drainage may also influence DOC/WEOC. Land use and management practices affect DOC/WEOC content in soils, but the effects are not well known. Since there is no optimum, absolute value, soil quality assessments require measuring the current DOC/WEOC contents and composition in un- 
disturbed areas, considered as desired values, and compared the results to disturbed areas.

DOC production and consumption depend on microbial activity and the product input. The main sources of DOC in soils are photosynthesis, plant litter, soil humus, and root exudates (Kalbitz et al. 2000). However, it is not clear whether DOC originates primarily from recent litter or from relatively stable organic matter in the lower part of organic horizons (Kalbitz et al., 2000). Humified organic matter is the major source of DOC due to the relatively high proportion of humus in relation to litter in soils (Zsolnay, 1996). Microbial biomass is also considered a potential source of DOC, and microbial metabolites constitute a significant proportion of DOC (Kalbitz et al., 2000). Nevertheless, it is difficult to quantify the relative proportion of DOC produced by plants or microorganisms. In some cases, where nutrient supply is not limiting, forest soils have DOC and WEOC concentrations higher than farmed areas because of the higher microbial activity. Fungi play a significant role in DOC production and the higher fungal biomass in forest floor compared to agriculture soils or impacted areas may be an explanation for differences in DOC and WEOC contents. Surprisingly, Smolander \& Kitune (2002) found that DOC chemical composition is not affect by plant species. These results contradict the concept that much of the DOC originates from the soluble organic matter present in fresh litter (Qualls et al., 1991). It is possible that the components of DOC change before being leached, and that modifies the characteristics of the soluble material.

Microbial transformation and immobilization, mineralization, precipitation and adsorption to mineral surfaces are involved in DOC degradation, and these processes are considered as a sink of DOC. The microbial mineralization of DOC is catalyzed by photolysis of DOC to low-molecular size compounds (Qualls \& Richardson, 2003). An approach to determining if DOC is a substrate for microorganisms is to measure $\mathrm{CO}_{2}$ production. A correlation between DOC and total mineralizable organic carbon could indicate to what extent DOC is labile. Additionally, microbial transformation may also immobilize $\mathrm{N}$ and $\mathrm{P}$, and this phenomenon is considered an important factor controlling the availability of these nutrients to plant uptake (Quall et al., 1991).

The equilibrium between DOC and solid SOC will affect the production of soluble compounds. DOC is replaced in solution as a result of the equilibrium with a large pool of potentially soluble organic matter by adsorption/desorption reactions (Qualls \& Richardson, 2003). Neff et al. (2000) raise the possibility that DOC fluxes, as well as DON and DOP, are controlled by soils physical rather than biological factors. These authors concluded that the strong relationship between DOC and DON flux and soil $\mathrm{C}$ and $\mathrm{N}$ contents indicates that DOC and DON fluxes are more closely related to overall pool of organic matter than the rate of microbial turnover. This pattern is more evident in mineral soils where sorption reactions may assume an important role controlling DOC fluxes. DOC adsorption to mineral surfaces is far more important than its decomposition in reducing DOC concentrations (Kalbitz et al., 2000). Jardine et al. (1989) found that physical mechanisms are involved in DOC adsorption and that hydrophobic organic solutes are preferably adsorbed by the soils than hydrophilic compounds. Consequently, hydrophilic molecules will accumulate in the soil solution because their lower affinity to adsorption by the solid phase.

Conversely, DOC may be an important intermediary in the fixing of organic carbon in soil, participating of its cycling. Even though carbon fixation is considered one of DOC sinks in soils, this process seems to be more important in deep layers, since in surface horizons the mineralization and incorporation into biomass are more important (Zsolnay, 1996). However, the mechanisms by which DOC is adsorbed are unknown. The transition of organic carbon from the so called "light" fraction (LF) to the mineral or "heavy" fraction (HF) is considered one of the most significant steps in $\mathrm{C}$ fixation (Zsolnay, 1996). The LF is relatively more labile than the HF, which tends to be more firmly fixed by the soil's matrix. Nevertheless, the role of DOC in the LF-HF transition is not well understood. Neff et al. (2000) observed that DOC fluxes are controlled by physical desorption, dissolution and sorption reactions in soil horizons and, in some cases, DOC is not correlated to $\mathrm{CO}_{2}$ production. Zsolnay (1996) observed that there is a complex equilibrium between the DOM and the immobile organic matter as a result of abiotic and biotic (bio)chemical reactions. SOC molecules show a distinct, relative affinity for the solid fraction and this pattern is often represented by the distribution coefficient (Zsolnay, 1996). Consequently, depending on the extent of the distribution coefficient, adsorption or desorption will control DOC dynamics and, further on, the carbon sequestration process.

Adsorption of DOC depends on the nature and properties of sites available to interact with the ions and molecules present in soil solution (Cornejo \& Hermosin, 1996). Soil clay minerals, metal hydrous oxide materials can adsorb organic matter. The association between organic matter and inorganic colloids in soils defines if the process of enrichment is more relevant that the depletion of carbon. Although the processes involved in DOC adsorption in mineral surfaces are hypothetical, it has been suggested that the affinity of this reaction depends upon the quantity and characteristics of indigenous organic matter and the mineral composition of the soil (Jardine et al. 1989). In this study, soils with higher $\mathrm{C}$ content showed lower DOC adsorption capacity, suggesting that the indigenous $\mathrm{C}$ unfavored further adsorption of added DOC. Mineral composition and crystalline and non-crys- 
talline Fe oxides and hydroxides contents also affected DOC adsorption.

Physicochemical mineralization of DOC and DON is also reported in the literature. In some cases, solar radiation is a pathway of mineralization, since it can enhance degradation of some refractory substance, mainly humic fraction (Qualls \& Richardson, 2003).

UV absorbance has been used to characterize DOC, but it is not always a reliable predictor for DOC biodegradability. On the other hand, nuclear magnetic resonance (NMR) spectroscopy has proven to be an useful tool to explain SOC decomposition. Liquid state ${ }^{13} \mathrm{C}$ NMR spectroscopy techniques have been used to assess the composition of organic acid in DOC. Few studies have compared the composition of DOC in impacted and non-impacted areas. Generally, larger molecules and organo-metal complexes are found forest soils when compared to intensively managed areas. In this case, DOC can be used as a parameter to evaluate the extension of degradation in disturbed areas and the effect of changes in land management associated with reduction in soil quality.

\section{Mineralization of the DOC and nutrient supply}

Dissolved organic matter carries not only $\mathrm{C}$, but also $\mathrm{N}, \mathrm{P}$ and metals, playing therefore a major role in determining accumulation, transport and balance of these elements in soils (Qualls \& Richardson, 2003). DOC is an important factor in determining the balance of soil $\mathrm{N}$ and P over the time of soil development (Qualls \& Haines, 1991) and it can contribute to cycling of soil nutrients (Smolander \& Kitunen, 2002). DOC, DON, and DOP fluxes play important roles in terrestrial $\mathrm{C}, \mathrm{N}$ and $\mathrm{P}$ budgets (Neff et al., 2000). However, the availability of nutrients is poorly understood and the affinity of DOC to adsorption by soil colloids may affect the regulation of dissolved organic nutrients (Qualls \& Richardson, 2003). Actually, sorption of DOC in subsoils is an important mechanism to control losses of organic nutrients from soils. The extent of this mechanism regulates $\mathrm{N}$ and $\mathrm{P}$ mineralization, and varies according to soil characteristics (Neff et al., 2000) and distribution of these elements among DOC fractions of different mobilities (Kaiser, 2001).

Over $90 \%$ of $\mathrm{N}$ is found in organic forms and this fraction plays an important role in plant nutrition (Kelley \& Stevenson, 1996, Goulding et al., 2000). Although DON or WEON can be measured in the soil solution, unlike $\mathrm{C}$, inorganic $\mathrm{N}$ forms cannot be separated by acidification. Ordinarily, organic $\mathrm{N}$ compounds are quantified by the difference between the total amount and the concentration of inorganic species, such as nitrate, nitrite, and ammonium (Zsolnay, 1996; Smolander \& Kitunen, 2002). However, organic $\mathrm{N}$ may be resistant to microbial degradation and, consequently, may be unavailable to be ab- sorbed by plants. This is caused, possibly, by the incorporation of $\mathrm{N}$ from amino acids and other amino compounds into the structures of humic and fulvic acids during the humification process. Besides the recalcitrant fraction, organic nitrogen also exists as labile, utilized by microorganisms, such as H-bounded peptides and proteins (Kelley \& Stevenson, 1996). However, DON fluxes are primarily regulated by overall abundance of $\mathrm{C}$ and $\mathrm{N}$ in SOC, instead of by microbial N demand. DON (and DOC) losses are closely related to microbial activity only when the soil capacity to stabilize soluble carbon is low (Neff et al. 2000). Satti et al. (2003) found that N mineralization was regulated by the quality of $\mathrm{C}$ in the litter (leaf litter lignin), and by the total $\mathrm{N}$ in the soil. Results from sequential extraction of DOC have shown that $\mathrm{N}$ is associated mainly with hydrophobic and hydrophilic acids fraction, and DON mobility is influenced by the presence of carboxylic, and perhaps phenolic groups (Qualls \& Haines, 1991). Smolander \& Kitunen (2002) found that the hydrophobic acid fraction was the most dominant, accounting for $40-55 \%$ of the total DON. However, Kaiser (2001) concluded that the hydrophilic DOM was N-enriched in comparison to the hydrophobic fraction, but the first showed lower affinity to be sorbed by mineral phases, while the hydrophobic molecules were strongly retained in soil. Consequently, organic matter remaining in solution showed higher $\mathrm{N}$ concentration and larger portion of hydrophilic compounds.

The dynamics of DON seems to be closely related to DOC, and might involve common processes (McGill \& Cole, 1981; Qualls, \& Haines, 1991). Sources of both DON and DOC are conceptually similar (Zsolnay, 1996). On the other hand, $\mathrm{P}$ is not an integral part of all molecules of DOC; instead, organic P is transported by more specific substances (Quall \& Haines, 1991). Some studies have shown that DOP concentration is not closely related to DOC concentration, and $\mathrm{P}$ contents are much more variable than the $\mathrm{N}$ contents (Qualls \& Richardson, 2003). Qualls et al. (1991) reported that the P contents in DOM are much lower than in throughfall, suggesting that the soil is a sink of inorganic $\mathrm{P}\left(\mathrm{PO}_{4}^{3-}\right)$ as well as mycorrhizae and $\mathrm{P}$ removal by roots. This difference in $\mathrm{N}$ and $\mathrm{P}$ behavior occurs because mineralization of $\mathrm{N}$ takes place in conjunction with biological $\mathrm{C}$ mineralization, while $\mathrm{P}$ mineralization involves both biological and enzymatic (biochemical) process (McGill \& Cole, 1981).

Monoesters are the most dominant form of organic $\mathrm{P}$ in soils. These compounds show different stabilization degree and they are totally derived from microorganisms (Magid et al., 1996). Thus, the chemical nature and dynamics of organic $\mathrm{P}$ in soils are determined by microbial products. However, phosphorus was not found to be a factor controlling the mobility of a large portion of 
the DOC, although anionic P esters may influence DOPcontaining molecules (Qualls \& Haines, 1991). On the other hand, Neff et al. (2000) found that fertilization with $\mathrm{P}$ increased DOP leaching and decreased both DOC and DON fluxes. DOP is largely affected by the throughfall and represents an important input of organic $\mathrm{P}$ into the soil (Qualls et al., 1991). Results from DOC fractionation showed that organic $\mathrm{P}$ is found mainly in the hydrophilic fraction ( $80 \%$ of bulk organic $\mathrm{P})$, and this $\mathrm{P}$-enrichment was more pronounced than that of N (Kaiser, 2001). Even though hydrophilic compounds can be more mobile into the soil profile than hydrophobic molecules, this study showed that the former was strongly adsorbed by subsoil horizons. Numerous experiments have shown that organic forms of $\mathrm{P}$ can reduce $\mathrm{P}$ fixation in soils with strong $\mathrm{P}$ affinity (Goulding et al., 2000). Organic ligands present in the DOC sorbs on to P-fixing surfaces, decreasing $\mathrm{P}$ fixation, thus increasing plant availability and utilization of $\mathrm{P}$. This pattern can be especially important in tropical soils that have high P-fixing capacity and low $\mathrm{P}$ concentrations (Andrade et al., 2002).

\section{CONCLUDING REMARKS}

Soil organic carbon can be considered a good indicator of a healthy soil system. Because DOC is more sensitive to changes in the environment than SOC as a whole, DOC is an alternative tool for monitoring adverse impacts of management on soil quality. Understanding the role of DOC in nutrient cycling is an important factor for sustainable ecosystem management. Although it is known that DOC can influence nutrient cycling in aquatic and terrestrial ecosystems, factors influencing the DOC bioavailability remains poorly understood. Because DOC may also contain most of the compounds that are the source of mineralizable $\mathrm{N}$ and $\mathrm{P}$, the availability of these nutrients is closely liked to DOC dynamics. There is the need for much greater information regarding processes involved in DOC dynamics, and what is the role of environmental conditions on soil quality. Biochemical reactions of $\mathrm{C}, \mathrm{N}$, and $\mathrm{P}$ are inextricably linked and abitotic and biotic factors controlling their dynamics can also play an important role in soil quality. Future research should address this subject, aiming to increase available knowledge on processes that govern SOC, N and P mineralization and/or immobilization in soils. Knowledge on how DOC contributes to the mobility of some metals and pollutants shall be regarded as the basis of sustainable management of soil.

\section{REFERENCES}

ANDRADE, A.T.; FERNANDES, L.A.; FAQUIN, V. Organic residue, limestone, gypsum, and phosphorus adsorption by lowland soils. Scientia Agricola, v.59, n.2, p.349-355, 2002.

BOUMA, J. Land quality indicator of sustainable land management across scales. Agriculture, Ecosystems \& Environment, v.88, p.129-136, 2002.
CARTER, M.R. Soil quality for sustainability land management: organic matter and aggregation interactions that maintain soil functions. Agronomy Journal, v.94, p.38-47, 2002.

CHAN, K.Y.; HEENAN D.P.; OATES, A. Soil carbon fractions and relationship to soil quality under different tillage and stubble management. Soil \& Tillage Research, v.63, p.133-139, 2002.

CHANTIGNY, M.H. Dissolved and water-extractable organic matter in soils: a review on the influence of land use and management practices. Geoderma, v.113, p.357-380, 2003.

CORNEJO, J.; HERMOSIN, M.C. Interaction of humic substances and soil clays. In: PICCOLO, A. (Ed.). Humic substances in terrestrial ecosystems. Amsterdam: Elsevier, 1996. cap.15, p.595-624.

GIL-SOTRES, F.; TRASAR-CEPEDA, C.; LEIRÓS, M.C.; SEOANE, S. Different approaches to evaluating soil quality using biochemical properties. Soil Biology and Biochemistry, v. 37, p.877-887, 2005.

GOULDING, K.W.T.; MURPHY, D.V.; MACDONALD, A.; STOCKDALE, E.A.; GAUNT, J.L.; BLAKE, L.; AYAGA, G.; BROOKES, P. The role of soil organic matter and manures in sustainable nutrient cycling. In: REES, R.M.; BALL, B.C.; CAMPBELL, C.D.; WATSON, C.A. (Ed.) Sustainable management of soil organic matter. London: CAB, 2000. cap.4, p.221-232.

HAYNES, R.J. Labile organic matter fractions and aggregate stability under short-term grass-based leys. Soil Biology and Biochemistry, v. 31, p.1821-1830, 1999.

HAYNES, R.J. Labile organic matter as an indicator of organic matter quality in arable and pastoral soils in New Zealand. Soil Biology and Biochemistry, v.32, p.211-219, 2000.

HAYNES, R.J. Labile organic matter fractions as central components of the quality of agricultural soils: an overview. Advances in Agronomy, v.85, p.221-268, 2005.

HAYNES, R.J.; BEARE, M.H. Aggreagation and organic matter storage in mesothermal, humic soils. In: CARTER, M.R.; STEWART, B.A. (Ed.) Structure and organic matter storage in agricultural soils. Boca Raton: CRC Press, 1996, p.213-262.

JARDINE, P.M.; WEBER, N.L.; McCARTHY, J.F. Mechanisms of dissolved organic carbon adsorption on soil. Soil Science of American Journal, v.53, p.1378-1385, 1989.

KAISER, K. Dissolved organic phosphorus and sulphur as influenced by sorptive interactions with mineral subsoil horizons. European Journal of Soil Science, v.52, p.489-493, 2001.

KALBITZ, K.; SOLINGER S.; PARK, J.H. Controls on the dynamics of dissolved organic matter in soils: a review. Soil Science, v.165, p.277304, 2000

KARLEN, D.L.; MAUSBACH, M.J.; DORAN, J.W.; CLINE, R.G.; HARRIS, R.F.; SCHUMAN, G.E. Soil quality: a concept, definition, and framework for evaluation. Soil Science Society of America Journal, v.61, p.4-10, 1997.

KELLEY, K.R.; STEVENSON, F.J. Organic forms of $\mathrm{N}$ in soils. In: PICCOLO, A. (Ed.). Humic substances in terrestrial ecosystems. Amsterdam: Elsevier, 1996. cap.10, p.407-427.

MAGID, J.; TIESSEN, H.; CONDRON, L.M. Dynamics of organic phosphorus in soils under natural and agricultural ecosystems. In PICCOLO, A. (Ed.). Humic substances in terrestrial ecosystems. Amsterdam: Elsevier, 1996. cap.11, p.429-466.

McGILL, W.B.; COLE, C.V. Comparative aspects of cycling of organic C, N, S and P through soil organic matter. Geoderma, v.26, p.267-286, 1981 .

NEFF, J.C.; HOBBIE, S.E.; VITOUSEK, P.M. Nutrient and mineralogical control on dissolved organic $\mathrm{C}, \mathrm{N}$ and $\mathrm{P}$ fluxes and stoichiometry in Hawaiian soils. Biogeochemistry, v.51, p.283-302, 2000.

PICCOLO, A. Humus and soil conservation. In: PICCOLO, A. (Ed.). Humic substances in terrestrial ecosystems. Amsterdam: Elsevier, 1996. cap.5, p.225-292.

QUALLS, R.G.; HAINES, B.L. Geochemistry of dissolved organic nutrients in water percolating through a forest ecosystem. Soil Science Society of American Journal, v.55, p.1112-1123, 1991.

QUALLS, R.G.; HAINES, B.L.; SWANK, W.T. Fluxes of dissolved organic nutrients and humic substances in a deciduous forest. Ecology, v.72, p.254-266, 1991.

Sci. Agric. (Piracicaba, Braz.), v.62, n.5, p.502-508, Sept./Oct. 2005 
QUALLS, R.G.; RICHARDSON, C.J. Factors controlling concentration, export, and decomposition of dissolved organic nutrients in the Everglades of Florida. Biogeochemistry, v.62, n.2, p.197-229, 2003.

SATTI, P.; MAZZARINO, M.J.; GOBBI, M.; FUNES, F.; ROSELLI, L.; FERNANDEZ, $\mathrm{H}$. Soil $\mathrm{N}$ dynamics in relation to leaf litter quality and soil fertility in north-western Patagonian forests. Journal of Ecology, v.91, p.173-181. 2003.

SMOLANDER, A.; KITUNEN, V. Soil microbial activities and characteristics of dissolved organic $\mathrm{C}$ and $\mathrm{N}$ in relation to tree species. Soil Biology \& Biogeochemistry, v.34, p.651-660, 2002.

STEVENSON, F.J. Humus chemistry: genesis, composition, reactions. New York: John Wiley, 1994.
WEIL, R.R.; MAGDOFF, F. Significance of soil organic matter to soil quality and health. In: MAGDOFF, F.; WEIL, R.R. (Ed.) Soil organic matter in sustainable agriculture. Boca Raton: CCR Press, 2004. cap.1, p.143.

ZSOLNAY, A. Dissolved hums in soil waters. In: PICCOLO, A. (Ed.). Humic substances in terrestrial ecosystems. Amsterdam: Elsevier, 1996. cap.4, p.171-223

Received June 21, 2005

Accepted July 26, 2005 